\title{
The problems with liberal consensus. Agonistic politics according to Chantal Mouffe
}

\author{
Anna SZKLARSKA*
}

\begin{abstract}
This article is a critical analysis of the most important assumptions of Chantal Mouffe's political philosophy, along with its original categories such as agonism, radical democracy and hegemony. The sources of her concept are indicated and certain difficulties that the author falls into are distinguished. The thread that is considered central to this philosophy, with the most profound practical consequences, is an attempt to demonstrate the futility of a liberal doctrine that values consensus and deliberation and proclaims an apology for individualism and rationalism. Mouffe's diagnosis strikes at the most important liberal values with the intention of discrediting them although she tries to creatively adopt others, such as pluralism. She proposes a new paradigm, much fairer than existing ones, because it does not negate the conflictive nature of politics. Does an agonist dispute and radical democracy really have a chance to undermine liberal axiology? Are we dealing with a breakthrough in thinking about politics?
\end{abstract}

\section{KEYWORDS}

antagonism; agonism; liberalism; democracy; hegemony; deliberation; political philosophy

* Ph.D., assistant professor, Department of Philosophy and Sociology, Pedagogical University of Cracow, Poland. E-mail: anna.szklarska@up.krakow.pl. 


\section{INTRODUCTION}

The aim of this article is to present the most important assumptions of the political philosophy of Chantal Mouffe, which is critical to liberalism: to capture its creative aspects on one side and its most glaring weaknesses on the other. What is the point of politics? Is agreement possible or is it an illusion of liberalism? These are the questions that the philosopher asks and to which she keeps returning. Before analyzing what exactly the subject of criticism for the contemporary Belgian philosopher is, it is worth considering the essence of the current, which is the target of her attack. Liberalism should not be equated with the approval of positive freedom, freedom towards something, because while still being liberalism in its minimalist version, it points us to negative freedom, freedom from, if it is sufficient for the individual. Interestingly, it is also the kind of freedom that Mouffe values highly. Liberalism is also an attitude that does not have to be followed by a clearly defined system of values and views, but by the acceptance of diversity or ideological neutrality in this regard. Liberalism means kindness to various positions, tolerance, willingness to make concessions, openness to other views, different goals, acceptance of actions inconsistent with one's own beliefs, as long as they do not pose a threat to anyone and do not cause harm to anyone. In this sense, liberalism does not have to be associated with any set of concrete, solid rules or even with economic doctrine (as in its beginning, when apology of freedom referred to economic relations, the right to property, exchange of production) as long as individuals are guaranteed respect for their fundamental rights. ${ }^{1}$ The latter requirement accounts for a certain affinity between the liberal doctrine and the democratic system.

\section{HISTORICAL VIEW}

In ancient Greece, war, conflict, and competition, conducted according to certain rules, were something noble and at the same time inevitable. Conflict, in which the ethos of combat was not respected, which allowed the annihilation of the enemy, was something illegitimate and barbaric. In modern times, Niccolo Machiavelli, who defends the ideals of both the fox and the lion, devoted most of his attention to the problem of political struggle and its methods. The

${ }^{1}$ This approach to liberalism is close to Bertrand Russell and Karl Popper, who believe that the essence of a liberal position lies not in what one's views are, but in how one has them. A liberal's views are never dogmatic but hypothetical, accompanied by the awareness that in the course of rational debate they can be overthrown. See: Russell, 1969: 71-72. Political liberalism cannot be equated with neoliberalism, which is a consistent economic theory - this is emphasized today by, among others Norberto Bobbio. 
next to study this issue were Karl Marx and George Sorel and various sociologists of conflict (Dahrendorf, 1957). Pierre Bourdieu emphasized power and symbolic violence. The philosophical dispute about how to understand and evaluate the struggle, conflict, confrontation and what methods to consider as acceptable is very old, for example it differentiated Georg Wilhelm Friedrich Hegel and Immanuel Kant. It also has its practical consequences in proposing specific systemic solutions and the implementation of legally legitimized methods of conducting a political dispute.

The homeland of liberalism was Great Britain of the 17th and 18th centuries, during the Industrial Revolution, liberal notions were sent to France from England, later gaining recognition in the United States. Elements of liberalism can be found even in the systems and doctrines of South American countries (although only at the beginning of the 20th century). It is significant that it did not catch on in Asia. Eastern religions are unable to adopt the idea of liberalism: in India the equality of people is questioned, and Confucianism in China elevates community beyond the individual - this is contrary to the liberal principle of individualism. In liberalism, the entities: political, social and moral are individuals, not groups. It is emphasized that individuals are characterized by rationalism and the ability to mediate or negotiate, which enables them to search for optimal solutions in a dispute.

Of course, liberal theories were subject to various revisions. Certain assumptions, however, turned out to be constant. The most important of them include individualism, freedom, free market economy, law, democracy, egalitarianism, universalism, progress and consensus. Meanwhile, the approach of the contemporary philosopher Mouffe denies the project of democratic politics without conflicts and criticizes the ideal of a reconciled civil society as fundamentally false. In her vision there are no partners or parties to the dispute, there is no optimization of solutions or a network of compromises. The horizon of peaceful debates or abstracting from selfishness (Rawls, 1971) gives way to a new model in which politics is a struggle for hegemony between groups that are competing with each other out of necessity. The partnership relationship is replaced by a hegemonic relationship. Concerned about the future of democracy, Mouffe proposes to replace the normative and conciliatory approach with a realistic one. Democracy does not so much remove the conflict as it helps to civilize it; to tame the barbaric nature of the conflict. Another assumption is as follows: the greater the pluralism on the political scene, the weaker (though inevitable) hegemony of the strongest faction. Here we are dealing with a new form of emancipation, which is not necessarily entangled in economism and the division of property, as Marx previously proposed. Mouffe dismisses the Marxist topos of class struggle, as well as his economism, as the horizon for her considerations. The economy, in her opinion, is one of the many areas of human activity in which linguistic operations play a special role. The creation 
of industrial workers to be saviors of mankind, or at least the dominant political force, was achieved through appropriate discourse. Mouffe diminishes the role of economic dependencies and emphasizes the importance of the specific linguistic structure of the social world. These are quite significant differences between Marx's concepts and those of Mouffe and Laclau. At the same time, she is openly averse to contemporary consumerism and global inequalities, accusing neoliberalism of strengthening them.

Mouffe, being aware of the differences within the liberal current itself, makes a universal accusation against it: that its dominant tendency, which is a combination of the ideals of rationalism and individualism, "impedes an adequate understanding of the pluralist nature of social reality, with the conflicts that pluralism entails, the conflicts for which there can be no rational solution” (Mouffe, 2005a). The philosopher believes that liberalism, by its very nature, disregards - or to state further: it negates the antagonistic dimension of every society and feeds on the dream of the possibility of achieving a universal consensus based on reason. Moreover, liberalism "fails to grasp the nature of democratic politics" (Mouffe, 2005a). For the same reasons, by relying on methodological individualism, it loses the opportunity to see the process of creating a collective identity or collective forms of identification. Regardless of which model it adopts - be it instrumental rationality (based on the idea of the market transferred to politics) or the more popular communicative (deliberative) rationality, it diminishes or even ignores the role of passions, affects and irrational forces, which often determine the shape of politics. Thus, liberalism denies the essence of politics, which is dispute, conflict and antagonism. There is not, and there cannot be, a permanent, rational or moral consensus, achieved through a noble debate in which the power of arguments prevails and ultimately unifies everyone - argues the philosopher. Moreover, each identity is relational: the condition for constructing an identity is the existence of a difference between the set of one's own goals, beliefs, values and the set of different ideas. Sometimes, it is a friend-enemy relationship; other times, in a weaker version, it is the us-them dichotomy. Of course, it is more advantageous to deal with the latter variant. In every relationship, potential or actual, antagonisms are waiting to arise, because people differ in their interests and worldviews, not at the level of individuals, but at group level (individuals are related to some and divided from others). Does this position, which assumes the collective character of identity, seem curiously close to conservatism? No, because according to Mouffe, identities, although constructed by the power of difference, in opposition to qualities and ideas that are distant from us, are in themselves something fluid, impermanent and contingent, which is easily deconstructed. They don't have any strong roots. They are not essential. They are not formed in advance. As she emphasizes, "there is no essential identity, only forms of identification" (Mouffe, 2015: 57). 
The essence of these divisions is not their durability, but their difference, the nature of which is not fundamental. Often, just having certain beliefs means being in opposition, but these can change at any moment. It is necessary to accept the occurrence of a conflict and make efforts to keep it as least destructive as possible. The idea is that "others should be seen not as enemies to be destroyed, but opponents whose ideas can be fought, even ruthlessly, but whose right to defend those ideas cannot be questioned" (Mouffe, 2015: 22). In the work Hegemony and socialist strategy, written together with Ernesto Laclau, Mouffe is most dedicated to the thesis that no permanent community is possible, she rejects any essentialist categories that assume the presence of stable elements organizing interpersonal relations. Collective identities, including national ones, "are always contingent constructs possible thanks to a wide range of practices, discourses and language games, which may undergo multiple changes and rearticulations" (Mouffe, 2015: 57). Mouffe, unlike Jürgen Habermas, emphasizes the importance of the irrational and affective dimension in the process of acquiring identity, even considering it to be the basic element. Yes, identities are constructed in discourse, but one should break with the classical understanding of discourse in the horizon of the logos. Piotr Sawczyński summarizes the meaning of this position as follows: "Social space should therefore not be considered in terms of essence, but discourse, that is, a series of temporarily stabilized, but never permanently established articulations" (Sawczyński, 2016: 75).

Mouffe is an anti-Hegelian, claiming that "every order is a temporary and impermanent articulation of contingent practices" (Mouffe, 2005a) and at the same time denying the existence of any deeper objectivity, external to these practices, which we could call the Zeitgeist, the laws of history, the manifestation of Reason, universal morality, ethical program, nature etc. Mouffe, assuming that a community is not given, but created, that there is a certain undeveloped area in the socio-cultural space, which many try to colonize, is inspired by Bourdieu. Mouffe's analysis also leads us to the conclusion that individuals seem to be destined to be the object of manipulation. Her approach is an attempt to conduct a thorough revision of the Marxist tradition. It is not, however, another installment of post-Marxism, which assumes that social inclusion is rooted in efforts by one social sector to represent all other sectors. In post-Marxist theories one social sector with its interests, goals and demands becomes the representative of the whole of society. Indeed, Mouffe presupposes the possibility of changing the identities of various groups so that their demands are correlated with each other (while maintaining differences and equivalence) (Laclau \& Mouffe, 2007: 193) and even the establishment of a more or less permanent new order due to the hegemonic moment occurring in radical democracy. However, she recognizes that it is impossible for society to function as a peaceful whole, centered around a dominant group, uniting 
around one primary goal (Mouffe, 1993: 20, 66-68). ${ }^{2}$ She defends the principle of democratic pluralism. As citizens, creating various political entities, we engage in many different undertakings, we perceive our interests as being radically different from each other. According to Mouffe, the political community is constructed in a hegemonic way, which means that there is a hegemon (appropriating for example the language) and many minority groups, often excluded, without access to power. Nevertheless, they exist and by their existence they influence reality.

\section{AGONIST POLICY PROJECT}

As the philosopher argues, "Opponents cannot be seen simply as competitors whose interests can be agreed by simple negotiation or reconciled by deliberation" (Mouffe, 2005a). The assumption that antagonism can be eliminated is an illusion. The proposal of the Belgian philosopher is as follows: one should tame the conflict, instead of trying to eliminate it. Antagonism should be replaced with agonism based on the us-them relationship, "in which each of the opposing parties, although admitting that there is no rational solution to their conflict, recognizes the rights of his opponent" (Mouffe, 2005a). It is about mutual respect for the fact that the conflict takes place in a common symbolic space, without seeking a common solution: a "third way", a universal view of the problem. Consensus will not emerge, but it does not mean that the other side can be insulted, humiliated, ridiculed, or treated with contempt. Agonistic confrontation is not an apology of crude violence, although it should be assumed that the public space is based on a certain hegemony, individual structures have a different character and range of influence (here you can see clear inspirations from Marx on the one hand, and Carl Schmitt ${ }^{3}$ on the other). The project of a communicative situation, promoted by Habermas, which is conducive to deliberation and having a rational character, is not simply a harmless, though erroneous theory, or a flawed regulatory idea, but is something much

${ }^{2}$ A similar interpretation of the work of Mouffe can be ascribed to Mark A. Wenman, according to which the philosopher is far from the perspective that subordinates various particular aspirations to a single goal, which is the establishment of society as a whole.

${ }^{3}$ Schmitt, generally speaking, proposed an antagonistic model of public space, he also distinguished between politics and the political. The former, according to the German philosopher, is a practical activity based on the distinction between friend and foe, while the political aspect is the ability of making this distinction accurately. (Schmitt, 2000: 198f.). Mouffe refers to his intuition and categories, e.g. she defines politics as a concrete practice taking place on the ontic plane, and the political as what determines the conditions for the possibility of this practice and concerns the way these conventional actions from social reality appear. The political is therefore not simply a political philosophy but a critical inquiry, getting to know and establishing the essence of its mechanisms (Mouffe, 2008: 23). 
worse: a utopia with strong claims to arrange reality according to a specific pattern, and this, like any utopia could be dangerous.

Ludwig Wittgenstein in his concept of language games, expressed in the work Philosopbical investigations, argued that we speak different languages and that the compatibility of languages, just like an agreement of views, is not possible. One should accept the fact that there is always some authoritarian discourse that dominates others, within which it becomes possible to distinguish differences, dialects and regional specificities. It determines the rules of using the language, for the meaning of the word the model cases are important. Certain games have absolute rules that determine the correctness of the language, although sometimes they are so obvious that they are imperceptible. We express our thoughts in language, which is available to us as a species, not as an individual. For Mouffe, human multitude is inextricably linked with diversity (on this point the philosopher agrees with Hannah Arendt), although the same multitude and diversity is and must be a source of conflict. Meanwhile, the praise of Arendt's pluralism was liberal because it was based on the assumption that agreement was always possible. Mouffe herself raises this issue, distancing herself from Arendt and pointing to assumptions that she disagrees with: "According to Arendt, to think politically means to develop the ability to perceive reality from many perspectives. [...] In fact, what she is looking for is a procedure to ensure that an intersubjective agreement is reached in the public sphere. [...] Arendt ultimately envisions the public sphere as a space where consensus can be reached" (Mouffe, 2015: 25). Arendt identified the political with the space of freedom and public debate. Mouffe understands it differently, as the antagonism underlying every society, pluralism, which "entails the inability to finally reconcile all points of view" (Mouffe, 2015: 134). She distinguishes the political from politics, which she defines as "a set of practices and institutions which, in the face of a conflict introduced by the politics, create an order that enables human coexistence" ${ }^{4}$ (Mouffe, 2008: 24). Politics organizes and enables human coexistence. Mouffe understands that conflicts will not disappear. Her point is for conflicts to take an agonic form, of a dispute much softer than the antagonistic war between representatives of hostile civilizations. She also disagrees with those who, starting from antagonistic assumptions, conclude that the only way to prevent a civil war is an authoritarian order, and present this solution as a logical consequence of their ontological diagnosis. She is also against the notion "that establishing democracy requires westernization" and defends the thesis "that the democratic ideal may take different forms in different contexts" (Mouffe, 2015: 13). The desire to transfer the Western

${ }^{4}$ This distinction is brought up again in her later work, Agonistics. Political thinking about the world, where she writes: "politics is the name of a set of practices and institutions that organize human coexistence. However, these practices always operate within the conflicting forces behind which stands the political" (Mouffe, 2015: 10). 
liberal model of democracy to the whole world, to universalize values and goals strikes the basic truth about the human condition, which is based on freedom. In order to be free, a person must have a choice between real and different perspectives of life in its every dimension. Meanwhile, the institutions regulating international relations demand uniformity. Borders and all instruments conducive to the consolidation of social, cultural and political belonging are criticized. Mouffe stands up against the universal premises, the daydream of a truly global, borderless world, which imposes on some states the systemic solutions promoted as the only correct ones. Individual regions have their own specific problems, traditions, thought patterns and ways of evaluating; therefore, different local models of democracy should be accepted (Mouffe, 2008: 47). Even if their peaceful coexistence is not always possible and condemns people to constant competition for influence. Mouffe criticizes Antonio Negri's negative image of local and national conflicts described in The empire (Mouffe, 2008: 131). First of all, she mocks the conviction of moral superiority, characteristic of liberals, and the recognition of the model of liberal democracy as the only one appropriate for the civilized, modern world. As she writes:

democracy understood as the rule of the people may take other forms - for example, those where community values are of greater importance than individual freedom. According to the dominant view [...] moral progress requires the acceptance of the Western model of liberal democracy, because only this provides the institutional framework for the implementation of human rights. This thesis should be rejected, but it does not mean that the idea of human rights has to be abandoned (Mouffe, 2015: 42-43).

Mouffe looks for functional equivalents of the concept of human rights in other cultures, based on different traditions and values, where key decisions are made less individually.

\section{THE IMPORTANCE OF CULTURE AND ART AS A TOOL OF AGONISTIC CONFRONTATION}

Piotr Sawczyński proposes to interpret Mouffe in the spirit of the poststructuralism that inspired her. In this paradigm, the task of politics is a specific kind of liberation, or more precisely, the orientation of the subject "to such imaginary orders that will not claim to comprehensively explain the world (necessarily in a false way), but will leave it a space for negotiating meanings" (Sawczyński, 2016: 61). For Mouffe, politics is based on the ordering of social relations, and it is impossible to eliminate conflicts and well-functioning hegemony from it. In such an approach, art, artists, works and artistic practices begin to play an exceptional role. As she writes: "Artistic interventions are necessary to face the conviction that there is no alternative to the present 
order" (Mouffe, 2015: 14). Let us be reminded that for Mouffe, identity is not something rigid or imposed. It constitutes a construction and is subject to various influences, including the discursive and the aesthetic. The field for artistic practices and their impacts seems to be considerable. Moreover, art has another important function, it can weaken the leading narrative and hegemony of those in power.

According to the agonist approach, critical art is one that incites discord, bringing to light what the dominant consensus tries to obscure and blur. It is about giving a voice to all silenced under the existing hegemony, bringing out the multiplicity of practices and experiences that make up the fabric of a given society, along with the conflicts they entail (Mouffe, 2005a).

Therefore, art is not meant to unite the community with a universal message that everyone would approve of, but instead it is meant to divide, incite, and counterbalance the dominant discourse inspired by the hegemon. Art should be conducive to agonistic confrontation. Additionally, in the context of disputes over memory, heritage, identity, and past events, its task should be to support the defeated and give them a voice in order to question the narrative of the winners, in favor of the losers. The artist's task is to arouse anxiety and to intervene wherever everyone agrees as to the interpretation of history, the hierarchy of values, and the meaning of events. ${ }^{5}$ Facilitating a breakthrough to the surface of niche and even provocative perspectives is important, not simply because they are suppressed, but in the name of competition between collective memories, so that all conflicting voices can resonate, leave a trace and sometimes shake and provoke reflection. As Karol Morawski notes: "Laclau and Mouffe [...] are distrustful of great meta-narratives because, as they believe, any totalizing view of history implies the danger of totalitarian control over social heterogeneity" (Morawski, 2016: 214). At this point, the philosopher seems unexpectedly compatible with the liberals for whom pluralism is an unquestionable value. On the other hand, she introduces the category of a hegemon and, as it is known, this is generally understood as a love of uniformity: a uniform image of the world, values and law. Each hegemony

${ }^{5}$ The matter goes beyond the importance of critical art in the domain of agonistic disputes over history, heritage, or identity. At this point, it is worth emphasizing the existence of artistic practices that undermine the hegemony of neoliberal economics. More and more artists expressing themselves in the space of film, photography, reportage or advertising question modern liberal solutions. Subversive discourses as an expression of opposition to the prevailing economic relations and unreflective consumerism constitute critical, "demythologizing" interventions in the broadly understood pictorial and symbolic domain. For example, in "Projection from Tijuana" (2001), Krzysztof Wodiczko shows Mexican women working in a border complex of factories employing cheap labor. Artists such as Wodiczko and Joanna Rajkowska consciously refer to the concept of Mouffe's "agonist democracy”. 
awakens the appetite for an ever-greater advantage of one cultural and social pattern. However, in Mouffe's view, the hegemon is a figure that describes the status quo, but is by no means totally inclusive. Her desire is that the excluded rest, who question the hegemonic perspective and do not fit into her program of action, be noticed and valued. The minority deserves respect also for pragmatic reasons - today's other may himself become a hegemon tomorrow. Therefore, it is important that the rules of the political game are respected by everyone.

\section{A PROJECT OF RADICAL DEMOCRACY IN PLACE OF LIBERAL ONE}

To sum up, in Mouffe's opinion, deliberative democracy contradicts reality itself, pushing for a model that does not take into account the conflictogenic nature of politics: "Conflict, hostility has no rational causes - they are simply the basic form of existence of society" (Koczanowicz, 2015: 8). Liberals feed the public with the illusion that conflict can be overcome and resolved using the power of rational arguments, but it is an illusion that can intensify ideological conflicts on one hand, and on the other the growth of bureaucratic institutions that constitute a facade buffer. Instead of a narrative about the ultimate elimination of hostility and division, it would be better to acknowledge the disagreement on many issues, but nevertheless turn a hated enemy into a worthy opponent and replace war with a fight that has an ethos. When fundamental beliefs are in conflict with each other, the search for a common denominator is no longer possible. This is the case in the dispute over the scope of legitimizing abortion or the rights of non-heterosexual relationships. On the other hand, the apparent broad consensus, which gives the impression of a strong center, strengthens the extreme, populist movements as being expressive and more convincing, because they are credible, vital and avoid smooth, politically correct messages which evoke unfortunate associations with marketing efforts. The political center operates on catchphrases, general phrases constituting a set of slogans that do not arouse controversy or emotions, when politics is a pulsating dispute between different visions of a good life. The radical democracy proposed by Mouffe radicalizes liberalism, combining multiplicity with conflict, because these are the challenges of modernity, in which, according to the philosopher, façade institutions keep on compromising themselves because they do not offer any real solutions.

Meanwhile, the essence of democracy is the conflict of positions, Mouffe does not give up the idea of pluralism as an important component of democracy. Conflict is not an anomaly, a threat that should be eliminated immediately. As Maciej Gdula writes: 
The conflict divides people, but also connects them with each other, giving them a sense of participation in political struggle and the experience of agency. Instead of the exclusion offered by conflict-free models wishing to end politics, we are dealing with political participation in the creation of a common world (Gdula, 2008: 13).

Citizens propose various, alternative concepts of arranging the social world, all of them should be presented, considered and criticized, but one should ask: but how, if not in the framework of the ongoing debate and discussion? Mouffe is primarily reluctant to deliberation. She considers it as a futile undertaking but assumes that the guarantee of citizens' sovereignty is the possibility for them to choose one of the visions of socio-political reality from among the proposed, competing models. Only if everyone has a chance to be heard will they be a viable alternative. They are to be presented and discussed not as a starting point for reaching a consensus, a new quality that will emerge from the existing proposals, but with full awareness that the choice of one model excludes the implementation of others. The choice of one model means the (perhaps temporary) decline of another. One has to accept it. According to the philosopher:

politics is not the aggregation of individual preferences, but the clash of opposing camps. This does not mean a regression to tribal identifications, but on the contrary it means a process of connecting people separated from each other by class, gender, ethnic or religious identifications in a joint effort to achieve political goals that transgress particular interest (Gdula, 2008: 12).

Elsewhere, she asks a rhetorical question: "There is a lot of talk today about dialogue and deliberation, but what are the meanings of these words in the political field [...] when participants in the discussion cannot choose between clearly different alternatives?” (Mouffe, 2008: 18).

Mouffe proposes opening up to a new democracy without its liberal component. She is foreseeing the exodus of ever larger groups from the familiar form of democracy. As she argues, liberalism, contrary to what is commonly proclaimed, strikes at the very core of democratic values and dismantles democracy:

Western liberal democracy is an expression of two traditions: liberalism, with its emphasis on freedom and pluralism, and democracy, postulating equality and universal sovereignty. While both have important advantages, they are ultimately irreconcilable. [...] Under the conditions of neoliberal hegemony, the liberal component began to dominate so much that democratic values were undermined (Mouffe, 2015: 127-128).

This is a strong accusation that Mouffe believes is shared by many ordinary citizens who contest the inequalities existing in liberal society, as reflected in their recent "electoral" awakening in some European countries and the USA. 


\section{ALLERGY TO ANTAGONISM AND ITS CONSEQUENCES}

For Mouffe, all defenders of the consensual form of democracy, imagining the goal of democratic politics in terms of consensus and reconciliation, and having an idealized image of human nature and socialization, not only make a conceptual error, but also contribute to certain political threats. As she cautions: "striving for a world in which the we / them distinction will be overcome is based on wrong premises, and those who share this point of view fail to see the real tasks of democratic politics" (Mouffe, 2008: 17). She puts the matter even more acutely elsewhere:

Violence and hostility are considered an archaic phenomenon that can be eliminated by developing discussion and institutions, under a social contract, and by establishing transparent communication between rational actors. Opponents of this optimistic point of view are automatically considered enemies of democracy (Mouffe, 2008: 18).

However, Mouffe remains close to the critique of liberalism proposed by Schmitt, who believed that rational consensus was not possible and that any compromise is paradoxically based on exclusion. Schmitt and Mouffe criticize both the aggregative and the deliberative model of liberalism. ${ }^{6}$ With one exception. Mouffe disagrees with Schmitt's contention that a democratic political community leaves no room for pluralism. Her aim is to overthrow the hegemony of liberalism, in which "the dominant rationalist and individualistic approach makes it impossible to recognize the nature of collective identities" (Mouffe, 2008: 25). She wants to preserve the us-them opposition while maintaining pluralism. The author also wrote in her book In sefense of left-wing populism that the sudden outbreak of populism, inspired by the aversion to elitism, should push us to return to politics understood in this way. We should break the conviction that recognizing the irrevocability of the conflict in social life will undermine the foundations of the democratic project.

Mouffe aptly notices that the political overlaps with morality, and that political problems are cynically played out in the moral register. This does not mean that the us-them dichotomy is abandoned, it is still valid, but it is emphasized in the ethical context. The language of the dispute changes and takes on a moral character. The fight between right and left is replaced by the fight between right and wrong: we do not ask about the social and economic effects

${ }^{6}$ In the first paradigm, politics is about building a compromise using appeal to rational interests, in line with the liberal idea of the market. The second paradigm emphasizes the relationship between politics and morality. A rational compromise is justified here no longer by common interests, but by a moral consensus. Both models emphasize the communicative nature of interpersonal relations, although it is particularly exposed in the deliberative paradigm (Mouffe, 2008: 28). 
of abortion, the policy of equality or decommunization, but we argue about their moral evaluation. This approach legitimizes the brutality of a struggle that is no longer pragmatic and becomes a struggle for justice. It is difficult to withdraw from such a struggle, because it is not simply about benefit or interest, but about the victory of good over evil, about who is right in the dispute over the future of humanity. What is at stake can be dizzying.

Instead of expressing the us-them opposition as a political confrontation between opponents, it is presented as a moral confrontation between good and evil, in which the opponent can only be seen as an enemy that must be destroyed. And this is not conducive to the agonizing approach (Mouffe, 2008: 20).

Another manifestation of the moralization of politics is the narrative based on the search for the mythical common good, which assumes the unification of desires and needs.

There are no collective identities without a fundamental us-them distinction. Liberals believe that the task of democratic politics is to overcome this distinction: to establish trade-offs between particular interests and values. Trying to extinguish emotions in politics is not a good idea, because one should not be afraid of confrontation. Slogans praising tolerance and shared values cannot replace the need for identification correlated with collective passions which are essentially stimulated by bias. Mouffe is opposed to the unipolar order and instead proposes the implementation of a multipolar world with equilibrium between several regional centers. This would be a cosmopolitanism that allows for the coexistence of hegemonic centers of power that oversee the rule of souls.

\section{CRITICISM OF MOUFFE'S APPROACH}

One may wonder to what extent Mouffe is an original thinker, or whether she goes beyond a simple compilation of the theory of politicality defining the division between Schmitt's friend and foe and Marx's class struggle theory and the poststructuralist paradigm.

Any philosophy that gains a certain popularity makes people reflect and, to some extent, translates into the practical dimension of social, political or cultural life. For example, Kant's moral philosophy was conducive to the dissemination of the belief that the dignity of every human being must be respected. It became the basis of the concept of universal human rights, and his political philosophy promoting the idea of a peaceful alliance of many nations constituted the foundations of the European Union project. Marx's philosophy evolved into numerous strands that were the ideological basis of the universal 
proletarian revolution, and Herbert Marcuse's theory accelerated, if not paved the way for, a twentieth-century cultural revolution. It would be hard to imagine the philosophy of capitalism without Adam Smith's theory or modern feminism without the influence of Simone de Beauvoir. Mouffe proclaims that there is no need to eliminate fundamental conflicts from politics, because they are its essence. Ultimately, the discourse which has a linguistic, numerical, institutional and media advantage prevails, and the winner does not have to take into account the loser's reasons in this ideological duel, but can devote himself with all his energy to implementing his vision of the state and the good life in it. However, one may wonder whether in such a situation the political struggle becomes a fight for everything: for life and death. Losing must mean receding (at least for a while) into political non-existence and the assurance that no one will be truly interested in hearing our arguments. Such an approach can strengthen populism and foster crude manipulations and rhetorical tricks in an area which should be based on law, prudence, care for the common good, and interpersonal solidarity. The stakes are high, and hegemony precludes cooperation. It was for a reason that the Duke of Machiavelli acted alone, and here also other reasons, perspectives and values cease to matter. Mouffe's praise of pluralism seems to be illusive.

It is known that deliberative democracy is not about the rule of majority. Liberals believe that achieving increasingly complex perspectives is the measure of social progress. Already in the 1940s, one of the most brilliant philosophers of liberalism, Popper, pointed to the weaknesses of the traditional understanding of democracy as the will of the majority. Popper praised a system which guarantees respect for the law, an independent judiciary, and social control, which enforces responsible governments and fosters the free development of civil society. As he wrote: "We are democrats not because the majority is always right, but because democratic institutions, when rooted in democratic traditions, are the least evil" (Popper, 1963: 351). He also emphasized that fundamental to democracy is the possibility of a bloodless change of power. Democratic institutions make it possible to get rid of inept power without shedding blood and fueling internal tensions. After all, it is about searching for the best solutions, about dialogue, about making an effort to understand a separate perspective. It is about interpersonal kindness and respect for each person. "There is no enemy in this vision: there is either a partner in the discourse, or an opposing party in a court trial, or a supporter of a different way of interpreting the general principle" (Koczanowicz, 2015: 8). As Leszek Koczanowicz aptly notices: "For liberals, an ideal society is a society of rational discourse [...] For the opponents of liberals, society is always organized by violence, the advantage of one of the groups that imposes its views and rules on others" (Koczanowicz, 2015: 9). Marx assumed that the unity of all mankind in one fraternal society, in which there would be no divisions 
into classes and no strife between them, will constitute the final stage in the development of history. In order for this longed-for moment to come about, a prior revolution of the proletarians is necessary, who, by freeing themselves, will liberate all humanity and will not hesitate to use the most radical measures for the sake of a higher goal: the desired, utopian "kingdom of freedom". Meanwhile, let us not forget that Mouffe is a philosopher who revises some of Marx's assumptions, but remains in the orbit of Marxism, although she uses a softened language - she calls competition and violence "a permanent possibility" (Mouffe, 2005b: 147). The philosopher thinks in terms of a struggle between parties, and at the same time presents an ironic attitude to classical liberalism. She argues that the liberal democracy praising rationality has compromised itself, also through the paradoxes into which it falls. On the one hand, liberalism would be based on a naive, overly optimistic, idealized image of human nature, on the other, it would justify the need for consensus with the fear of war (if we do not agree, all we can do is fight). But what should we be afraid of if we are social beings who are clearly kind to each other? one may ask mockingly. Mouffe's proposal seems to be even more paradoxical. It is true that the hegemonic relationship that underlies the order she proposes to some extent removes the atmosphere of constant political and social struggle (in the name of the principle that the winner takes everything, establishes a hierarchy and takes full political responsibility), but at the same time it relies on it. This is the true "paradox of democracy" which, on the praxis level, is always a radical democracy and no other. Hegemony is an apparent guarantor of order: establishing such an evaluation leads politics to the path of irrational and at the same time ruthless war, which is legitimized by the fear of the opponent's victory. The philosopher's assumption is that agonism is meant to moderate antagonism, but the figure of the hegemon, central to her philosophy, is by no means conducive to this.

Mouffe's theory as a diagnosis of political reality may seem correct in the context of some phenomena. In Poland, individual parties are not interested in dialogue, mutual respect and searching for a compromise, but in eliminating a different perspective and those who propose it from public life. And so, representatives of various ideological circles do not talk to each other, but make accusations against their opponents and treat any interactions with representatives of the "hostile" camp as an opportunity to demonstrate their superiority (moral, economic, cultural) - each party understands and defines this advantage differently. Liberals tend to emphasize the rule of law, tolerance and diversity, while conservatives focus on the apology of high moral standards. Meanwhile, constructive dialogue cannot be based on the will to humiliate the opponent or pride and the belief in one's own infallibility. It often leads to media manipulations that facilitate the attacks on the opposing camp and maintain the coherence of the narrative at all costs. Nobody is interested in an 
authentic dialogue; the point is that all the premises must clearly confirm the division into a good and a bad political camp. In this way, however, building a community and joint action becomes more and more unreal and abstract.

Ultimately, there is no neutral plane that would create the conditions for agreement and reconciliation of conflicting interests - argues Mouffe. However, one might ask why universities and scientific institutions could not serve a cold, objective, rational debate in which the goal would be the search for truth achieved through presenting sound arguments, while all other goals would be considered unworthy. Mouffe considers Rawls' veil of ignorance, which would serve to suspend the dispute and allow it to be resolved while abstracting from who you are and what you are striving for, as being an artificial construction: a thought experiment detached from reality. Thus, as a result, it leads to rejection of the idea of dialogical democracy and dialogue itself as the basis of a democratic system.

In any case, Mouffe's concept is not directly normative but descriptive, and that is where its value lies, it is a brilliant description of politics and its mechanisms in a democratic society divided in a dispute over values. Undoubtedly, however, the "transformation of antagonism into agonism, and the enemy into adversary is also an ethical challenge" (Koczanowicz, 2015: 194) an aspect which Mouffe in a sense downplays. The ethical side of Mouffe's work is also emphasized by Morawski, in his opinion: "the theory of radical and pluralist democracy is a defense of the values of pluralism and negative freedom" (Morawski, 2016: 203). However, Mouffe wants to be first and foremost a political theorist, who highlights certain disturbing phenomena and trends that may also have negative consequences for democracy itself. She considers the mixing of political and ethical order and language to be most dangerous. Defining opponents inconsistently with the facts, i.e. not as political opponents which they really are, but from a moral perspective, leads to not treating them as opponents, but as enemies who can and even should be eliminated (Mouffe, 2015: 145).

And yet, she is not only an observer, she makes certain postulates that undermine the sense of the current economic and political model, which is implemented under the system of Western liberal democracy. She argues that "in many countries where products are exported, the consequences of free trade are dramatic" (Mouffe, 2015: 71). In her thinking, which is clearly left-wing and close to the views of Marcuse (to which she does not refer directly), and opposed to the culture of booming consumerism: to the neoliberal economy constituting a continuation of former colonialism and leading to the division into poor, exploited countries and rich, exploiting countries. She is ready to accept economic protectionism and a radical overhaul of global trade relations, which re-evaluates the unfair division into poor and rich countries. Does a Belgian thinker, who wants to convince her readers that they need an alternative, have a chance to influence global geopolitics in the economic dimension? After 
all, we know that "ideas have consequences" (Weaver, 2013), as it has become apparent e.g. after the publication of Robert Nozick's Anarchy, state, utopia which influenced the politics of Margaret Thatcher and Ronald Reagan.

We can make certain charges against every doctrine. In the communitarian model, a community closes itself off within its own borders and loses openness to development. Its values are subordinated to the supreme, though a timidly expressed goal: the unification of society. The communitarians present themselves as defenders of the endangered tradition. It is true that they are sympathetic to the individual reflection of the community's narrative but are generally reluctant to deeper differences within it. Meanwhile, the identity constituted by difference (let's call it conventionally liberal) is a much more ambitious project and Mouffe is aware of it. In fact, she consistently postulates diversity in her works. ${ }^{7}$ Yet she aims her guns at the liberal project (as ultimately utopian) and thereby weakens liberalism. It seems strange because the goal she would like to achieve seems close to the liberal approach. Mouffe's desire is to turn enemies into adversaries, to warm relations and to domesticate antagonism by turning it into agonism. This is to be done not only at the linguistic and declarative level, but "thanks to the fact that all parties involved in the dispute respect the formal requirements of the democratic procedure" and thus by "limiting the functioning of democracy to meeting only formal conditions" (Morawski, 2016: 193). It is known that liberals have great respect for the law defined by the stiff, formal framework and the requirement to obey it as a buffer against violence, humiliation, mockery, exploitation or theft. In Mouffe's approach, however, another goal comes to the fore: to avoid futile deliberation.

\section{TENSIONS PRESENT IN THE THOUGHT OF THE BELGIAN PHILOSOPHER - SUMMARY}

Most of the difficulties arise from Mouffe's ambiguous attitude to liberal axiology. Mouffe criticizes neoliberalism as an economic order but does not entirely reject the liberal doctrine. Radical and pluralist democracy is in a sense its further development.

On the one hand, Mouffe ridicules attempts to "extinguish emotions in politics", on the other hand, she strongly distances herself from the political that takes place in an ethical horizon: when the fight between "good" and "evil" replaces the conflict between the left and the right. However, a question may arise as to whether such images showing the clash between the forces of

${ }^{7}$ This is pointed out by Wenman, who interprets Mouffe by emphasizing the fundamental status of pluralism. Pluralism is the goal of radical democracy, while democracy is the means (Wenman, 2003: 588). 
"good" and "evil", "light" and "dark", "order" and "chaos", etc., do not speak in the most effective way? Are they not the images that most effectively organize the collective unconscious? Is politics even possible without such symbolic representations? This problem was already mentioned by Gustav Le Bon in Psychology of crowds. It seems to be a constitutive element for social narratives.

The tension between the descriptive and prescriptive side of Mouffe's philosophy should also be emphasized. The Belgian author argues with the tendency to provide normative models of behavior, which is characteristic of contemporary political philosophy, and the vision of politics as an activity in which rational and autonomously acting entities are involved. Nevertheless, the normative dimension (e.g. the transformation of antagonism into agonism; playing out a political conflict within institutional frameworks agreed upon by all parties involved; general criticism of neoliberalism) is a dimension that is constantly present in the concept of radical and agonist democracy. However, if hegemony were really to turn out to be a general mechanism for constructing a society, would it necessarily involve some or other normative propositions and directions of political involvement? The answer should be yes, otherwise it would mean promoting a world based on nihilism and anarchy. It would not be a world friendly to minorities struggling for respect of their rights, to which Mouffe is so sensitive.

\section{THE FUTURE OF DEMOCRACY: BETWEEN DELIBERATION AND VIOLENCE}

The goal of Mouffe's concept seems to be to remove the divide between the communitarian project (glorifying common memory, timeless values, etc.) and the liberal (glorifying individualism) project. One should accept the fact that the contemporary community is based on different assumptions - the philosopher argues. The second, minor goal is the affirmation of leftist ideas as an alternative and attractive ideological proposition, giving hope for a new shaping of social relations. Will the model of deliberative or non-consensual democracy win? Does abandoning consensus mean an irretrievably lost opportunity for agreement and consent between the parties and the citizens themselves? Will it not ultimately lead us to a fratricidal struggle and a desire to annihilate?

As Koczanowicz notes: "what seems to escape deliberation [...] are new forms and possibilities of dialogue. They often deviate from any standards of rationality, but they result in new, often surprising social movements" (Koczanowicz, 2015: 208). However, the author does not specify exactly which movements he means: collective, spontaneous demonstrations? Monological appeals of individual activists or various collectives? General strikes, self-proclaimed 
blockades of spaces of key importance for the functioning of the state? Street happenings? Controversial artistic projects or riots that go beyond civil disobedience? Legal activities of non-governmental organizations? Probably each of these types of activism is involved. Social movements may use various forms of articulation in order to express their interests, having at their disposal mainly a non-parliamentary battlefield. It is worth bearing in mind the consequences of the philosophy that advocates a retreat from deliberative democracy. Wise deliberation promotes cooperation, and its failure can be interpreted by many as an open invitation to anarchy, radical actions and even violence. Mouffe herself is not on the side of anarchy, she denies that there is "such a thing as an absolute democracy with multitude capable of self-organizing without any need of the state or political institutions" (Mouffe, 2015: 11). She therefore proposes establishing institutional channels for the agonistic expression of antagonisms, because she is convinced that if they are not there, we will face an escalation of violence. Antagonisms, hitherto suppressed and covered by a false narrative of a unifying consensus, may break out in the form of uncontrolled violence (Mouffe, 2015: 126). A harmonious, horizontal, romantic formula of pluralism is not possible, so one should constantly keep in mind potential antagonisms and seek legal and structural frameworks for them. In a democratic society, antagonism is natural, but the multitude should have some representative forms. Mouffe does not share the belief of some left-wing circles that this multitude, largely driven by affects and emotions, will be able to self-organize on such a level that the state will no longer be needed. A sovereign, expressive multitude will not avoid taking power, constructing an identity, selecting a hegemon, and striving to make the representation as universal as possible. The antipolitical approach is as utopian as it is liberal. The philosopher explains the meaning of her agonist model as follows: "antagonism is kept in check by the creation of institutions that make the conflict agonist" (Mouffe, 2015: 59). Now they just need to be specified.

\section{BIBLIOGRAPHY}

Dahrendorf, R. (1957). Soziale Klassen und Klassenkonflikt in der industriellen Gesellschaft. Stuttgart: Ferdinand Enke.

Gdula, M. (2008). Nie bójmy się konfliktu (s. 5-13). W: Ch. Mouffe. Polityczność. Przewodnik Krytyki Politycznej. (J. Erbel, Trans.). Warszawa: Wydawnictwo Krytyki Politycznej.

Koczanowicz, L. (2015). Polityka dialogu. Warszawa: Wydawnictwo Naukowe PWN.

Laclau, E. \& Mouffe, Ch. (2007). Hegemonia i socjalistyczna strategia. Przyczynek do projektu radykalnej polityki demokratycznej. (S. Królik, Trans.). Wrocław: Dolnośląska Szkoła Wyższa.

Le Bon, G. (1996). Psychologia ttumu. (B. Kaprocki, Trans.). Warszawa: Pavo.

Mazur-Bubak, M. (2019). A few problems with Mouffe's agonistic political theory. Polish Political Science Yearbook, 48(2), 307-318. 
Morawski, K. (2016). Dyskurs hegemonia demokracja. Analiza krytyczna projektu demokracji radykalnej. Warszawa: Wydawnictwo Naukowe PWN.

Mouffe, Ch. (1993). The return of the political. London-New York: Verso.

Mouffe, Ch. (2005a). Agonistyczne przestrzenie publiczne i polityka demokratyczna. (J. Maciejczyk, Trans.). Recykling Idei. Pismo społecznie zaangażowane, listopad. Retrieved from: https://recyklingidei.pl/mouffe-agonistyczne-przestrzenie-publiczne-polityka-demo kratyczna (24.06.2020).

Mouffe, Ch. (2005b). Paradoks demokracji. (W. Jach, M. Kamińska, \& A. Orzechowski, Trans.). Wrocław: Wydawnictwo Naukowe.

Mouffe, Ch. (2008). Polityczność. Przewodnik Krytyki Politycznej. (J. Erbel, Trans.). Warszawa: Wydawnictwo Krytyki Politycznej.

Mouffe, Ch. (2015). Agonistyka. Polityczne myślenie o świecie. (B. Szelewa, Trans.). Warszawa: Wydawnictwo Krytyki Politycznej.

Mouffe, Ch. (2020). W obronie lewicowego populizmu. (B. Szelewa, Trans.). Warszawa: Wydawnictwo Krytyki Politycznej.

Nozick, R. (2009). Anarchy, state, and utopia. Oxford: Blackwell.

Popper, K.E. (1963). Conjectures and refutations: The growth of scientific knowledge. London: Routledge \& Kegan Paul.

Popper, K.E. (2006). Społeczeństwo otwarte i jego wrogowie. (H. Krahelska, Trans.). Warszawa: Wydawnictwo Naukowe PWN.

Rawls, J. (1971). A theory of justice. Harvard: Belknap Press.

Russel, B. (1969). The autobiography of Bertrand Russell (vol. 3: 1944-1969). London: Allen \& Unwin.

Sawczyński, P. (2016). Polityczność podmiotu. Spór o podmiotowość polityczna w świetle zwrotu jezykowego. Kraków: Universitas.

Schmitt, C. (2000). Pojęcie polityczności (s. 191-250). W: C. Schmitt. Teologia polityczna i inne pisma. (M.A. Cichocki, Trans.). Warszawa: Aletheia.

Weaver, R. (2013). Ideas have consequences. London: University of Chicago Press.

Wenman, M.A. (2003). Laclau or Mouffe? Splitting the difference. Pbilosophy \& Social Criticism, 29(5), 581-606. 